DOI: $10.31073 / \operatorname{mivg} 201801-117$

Available (PDF): http://mivg.iwpim.com.ua/index.php/mivg/article/view/117

УДК 532.5:539.4:626/627

\title{
ОБГРУНТУВАННЯ ЗАХИСНИХ ПРОТИПАВОДКОВИХ ПОКРИТТІВ РУСЕЛ ГІРСЬКИХ РІЧОК
}

\author{
B.I. Петроченко1, канд. тех. наук, О.В. Петроченко ${ }^{2}$, канд. тех. наук \\ ${ }^{1}$ Інститут водних проблем і меліорації, Київ, Україна; е-mail: v_petr47@ukr.net \\ ${ }^{2}$ Інститут водних проблем і меліорації, Київ, Україна; e-mail: a_petr89@ukr.net
}

\begin{abstract}
Анотація. Розроблено методику обтрунтування конструктивних рішень та розрахунку параметрів захисних протипаводкових покриттів русел гірських річок. В основу методики покладено критерій стійкості захисних покриттів до розмивання та зрудення паводковим потоком розрахункової забезпеченості. Методика пропонусться для практичного застосування на стадії розробки проектів систем протипаводкового захисту.

Ключові слова: гірська річка, паводок, забезпеченість паводка, захисне покриття русла річки, капітальні та експлуатаційні витрати
\end{abstract}

Проблема та ії актуальність. Одним 3 основних заходів превентивного протипаводкового захисту є регулювання русел річок та їх кріплення. Такі заходи здійснюють переважно на гірських річках, русла яких є найбільш уразливими під час проходження руйнівних паводкових потоків. Для захисту русел гірських річок від руйнівної дії паводкового потоку використовують різні конструкції захисних покриттів: кам'яні, бетонні, дерев'яні, полімерні, біологічні, комбіновані та інші.

Проте, до цього часу науково-методичних засад з обгрунтування вибору конструктивних рішень та розрахунку параметрів захисних протипаводкових покриттів русел річок не створено. Проектні рішення захисних протипаводкових покриттів русел річок найчастіше приймають або 3 недостатнім, або із занадто великим запасом стійкості до гідродинамічних навантажень, що виникають під час проходження паводків. У першому випадку маємо економічні збитки, унаслідок руйнування паводковим потоком недостатньо стійкого захисного покриття. У другому випадку маємо невиправдано великі будівельні витрати.

Отже, одним 3 актуальних напрямів вирішення загальної проблеми протипаводкового захисту в басейнах гірських річок $\epsilon$ створення та практичне застосування на стадії проектування науково-методичних засад 3 обгрунтування конструкцій захисних протипаводкових покриттів гірських річок та їх параметрів як за критерієм забезпечення стійкості покриттів до руйнування паводковим потоком, так i за критерієм досягнення мінімальних будівельних та експлуатаційних витрат.
Метою дослідження $\epsilon$ підвищення технічної надійності та економічної ефективності проектів захисних протипаводкових покриттів гірських річок.

Основним завданням дослідження $\epsilon$ розробка методики обгрунтування технічно надійних та економічно доцільних конструктивних рішень захисних протипаводкових покриттів гірських річок та розрахунку їх параметрів.

Методи дослідження. У роботі використано системний та аналітичний методи дослідження комплексу природних факторів, що впливають на стійкість покриттів русел гірських річок до гідродинамічних навантажень під час проходження паводків.

Результати дослідження. Кінцевим науково-практичним результатом даного дослідження $\epsilon$ методика обгрунтування конструктивних рішень захисних покриттів гірських річок та розрахунку їх параметрів, яка пропонується для практичного застосування під час розробки проектів систем протипаводкового захисту. Суть методики та наукове обгрунтування ії основних положень викладено за такими розділами.

1. Визначення розрахункової витрати паводкового потоку.

Розрахункова витрата паводкового потоку $Q_{p}$ у річці є основним вихідним параметром на стадії розробки проекту протипаводкових заходів в басейні річки. Витрата $Q_{p}$ відповідас піковому значенню гідрографа паводка розрахункової (прийнятої за проектом) забезпеченості паводка $p$. За результатами досліджень [1] функцію витрати $Q_{p}$ від аргументу $p$ апроксимують на етапі передпроектних 
досліджень у вигляді спадної гіперболічної залежності:

$$
Q_{p}=\frac{k_{1}}{p}+k_{2}
$$

Невідомі коефіцієнти $k_{1}$ i $k_{2}$ знаходять за методом найменших квадратів на базі ряду емпіричних точок $\left(Q_{m}, p_{m}\right)$, отриманих за результатами гідрологічних спостережень за минулі роки. Кожну пару емпіричних точок $\left(Q_{m}, p_{m}\right)$ визначають, користуючись формулою:

$$
p_{m}=\frac{m}{n+1} \cdot 100 \% \text {, }
$$

де $n$ - кількість років спостережень, у кожному з яких була зафіксована максимальна витрата води в річці; $m$ - порядковий номер року, у якому зафіксовано витрату води $Q_{m}$ (найбільшу протягом $m$-го року); $p_{m}-$ забезпеченість паводка $m$-го року, або імовірність (у відсотках) перевищення протягом $n$ років витрати води у річці $Q_{m}$.

2. Визначення поперечних профілів русла річки.

3 огляду на можливі зміни по довжині річки трьох іiї основних показників: подовжнього уклону, фізичних властивостей грунтової основи, витрати води $Q_{p}$, річку ділять на окремі ділянки з визначенням розрахункових створів між ділянками. Приймається, що на ділянках річки захисні покриття можуть відрізнятись за конструктивними рішеннями, або за їх параметрами. На кожному j-му розрахунковому створі будують поперечний профіль русла річки 3 урахуванням руслорегулювальних заходів.

Руслорегулювальними заходами передбачено здійснення таких робіт: розчищення русла річки від мулу, поглиблення дна та розширення русла, випрямлення русла, спорудження берегових дамб (підвищення берегів), відкопування розвантажувальних каналів тощо. Для кожного характерного $j$-го створу річки визначають морфометричні характеристики поперечного перерізу русла i живого (водного) перерізу.

Поперечний переріз русла річки на j-му створі характеризується формою профілю (переважно у вигляді параболи) та основними морфометричними елементами: максимальна глибина русла $H_{j}$, ширина русла 3 урахуванням берм $B_{j}$, периметр профілю русла $P_{j}$. За поперечним перерізом русла річки на $j$-му створі визначають проектні параметри захисного протипаводкового покриття, основним 3 яких $€$ периметр покриття.

Живий (водний) переріз русла річки на j-му створі характеризується такими морфо- метричними елементами: площа $\omega_{j}$, максимальна глибина $h_{j}$, ширина водної поверхні $b_{j}$, змочений периметр $\chi_{j}$. За живим перерізом русла визначають гідродинамічні характеристики паводкового потоку, основною 3 яких $\epsilon$ середня швидкість потоку води $v_{j}$, яку визначають за формулою:

$$
v_{j}=Q_{p}^{j} / \omega_{j},
$$

де $Q_{p}^{j}-$ витрата паводкового потоку на $j$-му створі, $\mathrm{M}^{3} / \mathrm{c}$.

Якщо на j-му створі $є$ гідрометричний пост, витрату $Q_{p}^{j}$ визначають за формулою (1), використовуючи результати спостережень. У разі відсутності гідрометричного поста витрату $Q_{p}^{j}$ визначають за формулою:

$$
Q_{p}^{j}=Q_{p}+\sum_{\theta=1}^{j-1} \Delta Q_{H \partial}^{\theta}-\sum_{\theta=1}^{j-1} \Delta Q_{b m}^{\theta},
$$

де $Q_{p}-$ розрахована за формулою (1) витрата паводкового потоку на початковому (нульовому) створі річки, обладнаному гідропостом, $\mathbf{M}^{3} / \mathrm{c} ; \Delta Q_{н \dot{ }}{ }^{\theta}-$ витрата води, що надходить до річки з її притоки на попередньому $\theta$-му створі, м ${ }^{3} / \mathrm{c} ; \Delta Q_{e m}{ }^{\theta}-$ витрата витоку води 3 річки на $\theta$-му створі у протипаводкове водосховище або через розвантажувальний канал, $\mathbf{M}^{3} / \mathrm{c}$.

3. Визначення послідовності аналізу ма обтрунтування альтернативних варіантів конструктивних рішень захисних покриттів.

Першим критерієм вибору конструктивного рішення захисного покриття русла річки $\epsilon$ забезпечення стійкості покриття до розмивання та зрушення паводковим потоком. Другим критерієм є досягнення мінімальних витрат на будівництво та експлуатацію захисного покриття. Зваживши на це, доцільно перший критерій обрати за основний, за яким приймають проектне рішення, а процедуру аналізу та обгрунтування альтернативних варіантів захисного покриття слід починати 3 найбільш дешевого варіанту.

4. Визначення ділянок річки, що не потребують захисних заходів.

Ділянки русел річок не потребують кріплення, якщо розрахована за формулою (3) середня швидкість руху води $v_{j}$ не буде перевищувати допустиму нерозмивну швидкість $\left[v_{j}\right]_{2 p}$ грунтової основи русла. Для визначення швидкості $\left[v_{j}\right]_{2 p}$. використовують формулу Б.I. Студенічнікова (5), якщо $h_{f} / d_{j} \leq 600$ або формулу А.М. Латишенкова (6), якщо $h_{j} / d_{j}>600[2]$.

$$
\left[v_{j}\right]_{z p}=3,6 \sqrt[4]{d_{j} h_{j}}, M / c ;
$$




$$
\left[v_{j}\right]_{z p}=5 d_{j}^{0,3} h_{j}^{0,2}, \mu / \mathcal{C},
$$

де $d_{j}$ - середній діаметр частинок грунту, м; $h_{j}$ - глибина потоку, м.

Вихідними параметрами розрахунку середньої швидкості потоку води $v_{j} \epsilon$ витрата $Q_{p}^{j}$ i похил $i_{j}$ дна русла на $j$-й ділянці. Швидкість $v_{j}$ і площу живого перерізу потоку $\omega_{i}$ визначають методом поступового наближення, використовуючи формулу Шезі [2-4]:

$$
v_{j}=W_{j} \sqrt{i_{j}},
$$
$\mathrm{M} / \mathrm{c}$.

де $W_{j}$ - швидкісна характеристика потоку,

$W_{j}$ визначають за формулами:

$$
W_{j}=\frac{1}{n_{j}} R_{j}{ }^{2} ;(8) \quad R_{j}=\omega_{j} / \chi_{j}
$$

де $n_{j}$ - коефіцієнт шорсткості поверхні русла річки, який обирають за таблицею 7.4 [2]; $R_{j}$ - гідравлічний радіус, м; $\chi_{j}-$ змочений периметр, м; $Z$ - показник ступеня, який визначають за таблицею VI.2 [3] або за формулою M.M. Павловського [3]:

$$
Z=2,5 \sqrt{n_{j}}-0,13-0,75 \sqrt{R_{j}}\left(\sqrt{n_{j}}-0,1\right) .
$$

Після визначення методом послідовного наближення швидкості $v_{j}$ за формулою (7) iї порівнюють 3 максимально допустимою швидкістю $\left[v_{j}\right]$. Якщо на $j$-й ділянці річки встановлено співвідношення $v_{j}<\left[v_{j}\right]$, на цій ділянці захисне покриття не споруджують. Якщо на $j$-й ділянці має місце $v_{j}>\left[v_{j}\right]$, перевіряють варіант застосування захисного покриття 3 кам'яного накиду.

5. Розрахунок захисного покриття 3 насипних кам'яних матеріалів.

Найбільш простим конструктивним рішенням захисного покриття річки $€$ кам' яний накид уздовж змоченого периметра русла. Допустима нерозмивна швидкість $\left[v_{j}\right]_{k \mu}$ на $j$-й ділянці русла 3 кам'яним накидом може бути розрахована за формулою Б.І. Студенічнікова iз застосуванням рекомендованого коефіцієнта $K_{k \mu}=0,9$, за яким враховано ризик руйнування та втрати вартості кам'яного накиду під час проходження руйнівного паводка:

$$
\left[v_{j}\right]_{\kappa н}=K_{к u} 3,6 \sqrt[4]{D_{j} h_{j}}, M / c,
$$

де $D_{j}$ - середній діаметр каменя накиду, м; $h_{j}$ - глиб̆нна потоку, м.

Швидкість $\left[v_{j}\right]_{k н}$ також може бути визначена за таблицями 7.10 і 7.12 [2].

Середню швидкість $v_{j}$ і площу живого перерізу потоку $\omega_{j}$ для русла $з$ покриттям із кам'яного накиду визначають по аналогії 3 руслом без покриття, користуючись формулами (7)-(10). У разі $v_{j}<\left[v_{j}\right]_{\text {кн }}$ роблять висновок про доцільність використання кам'яного накиду для протипаводкового захисту русла річки на $j$-й ділянці. У разі $v_{j}>\left[v_{j}\right]_{k \dot{ }}$ приймають рішення про використання на $j$-й ділянці річки покриття зв'язаної конструкції.

6. Обтрунтування захисного покриття зв'язаної конструкції.

До захисних протипаводкових покриттів русел річок зв'язаної конструкції відносять: габіони; покриття у вигляді гнучких решіток, утворених із залізобетонних блоків стрижневого типу, порожнини між якими заповнені кам'яним накидом [5]; гнучке покриття із залізобетонних плит [6]; об'ємні геосинтетичні ковдри, завантажені заповнювачами тощо.

Зв'язані покриття русел річок через їх конструктивні особливості мають достатню стійкість до розмивання паводковим потоком, проте виникає потреба наукового обгрунтування їхньої стійкості до зрушення на поверхні земляного русла силою гідродинамічного тиску паводкового потоку.

Покриття зв'язаної конструкції, наприклад із габіонів, показано на рис. 1, поз. 2 (правий берег русла річки). Для визначення умов стійкості покриття зв'язаної конструкції на поверхні земляного русла запишемо рівняння Д. Бернуллі для руху одиниці об’ $€$ му потоку від (j-1)-го до $j$-го створу річки:

$$
\left(z_{j}-z_{j-1}\right)+\left(\frac{\alpha_{1} v_{j}^{2}}{2 g}-\frac{\alpha_{2} v_{j-1}^{2}}{2 g}\right)=h_{F},
$$

де $z_{j}$ і $z_{j-1}-$ п'єзометрична висота води у річці на $j$-му і ( $j$-1)-му створі, м; $\alpha_{1}, \alpha_{2}$ - коефіцієнти Коріоліса, що враховують нерівномірність швидкостей по плошині перетину потоку; $g$ - прискорення вільного падіння, м/ $\mathrm{c}^{2}$; $h_{F}$ - питомі втрати напору на подолання сил тертя води об поверхню покриття, м.

Зваживши на те, що розрахунок стійкості покриття виконують для пікової витрати паводкового потоку $Q_{p}^{j}$, яка триває довше, ніж період проходження елементарного об'єму води від (j-1)-го до j-го створу, можна вважати рух води на $j$-й ділянці квазіусталеним $\left(Q_{p}^{j}=Q_{p}^{j-1}\right)$. Це дає підставу вважати: $v_{j}=v_{j-1} ; \alpha_{1}=\alpha_{2}$. Крім того, для квазіусталеного руху води за умови $\omega_{j}=$ const п'єзометричний i гідравлічний похили співпадають. П'єзометрична лінія 9 паралельна подовжній лінії дна 10 (рис. 1), що дає змогу визначити:

$$
z_{j}-z_{j-1}=\Delta z_{j}=i_{j} L_{j}
$$


де $-i_{j}$ i $L_{j}-$ гідравлічний похил і довжина $j-і$ ділянки річки, м.

3 урахуванням наведеного, рівняння Д. Бернуллі (12) буде мати вид:

$$
i_{j} L_{j}=h_{F} \text {. }
$$

Для усього об'єму води $w_{j}$ між (j-1)-м і j-м створами $\left(w_{j}=\omega_{j} L_{j}\right)$ відповідно до (14) маємо рівняння:

$$
\Delta E_{j}=A_{j}^{F},
$$

де $\Delta E_{j}-$ зменшення потенційної енергії об'єму води $w_{j}$, який проходить шлях $L_{j}$, $\mathrm{H} \cdot \mathrm{m} ; A_{j}^{F}-$ робота сил тертя об'єму води $w_{j}$ о поверхню покриття, $\mathrm{H} \cdot \mathrm{M}$. $\triangle E j$ визначають шляхом інтегрування:

$$
\begin{aligned}
& \Delta E_{j}=\int_{z=0}^{\Delta z_{j}} \int_{x=0}^{L_{j}} \rho g \omega_{j} d x d z= \\
& =\rho g \omega_{j} \Delta z_{j} L_{j}=\rho g \omega_{j} i_{j} L_{j}^{2},
\end{aligned}
$$

де $\rho-$ густина води, кг/ $\mathbf{M}^{3}$.

Поділивши ліву і праву частини рівняння (15) на $L_{j}$, маємо:

$$
\Delta E_{j} / L_{j}=P_{j}^{2 \partial}=A_{j}^{F} / L_{j}=F_{j}^{\beta-n},
$$

$$
\text { звідки: } F_{j}^{\mathrm{e}-n}=P_{j}^{2 \partial}=\Delta g \omega_{j} i_{j} L_{j},
$$

де $P_{j}^{2 ১}$ - гідродинамічна сила, що діє на $j$-у ділянку покриття в напрямі руху води, $H$;
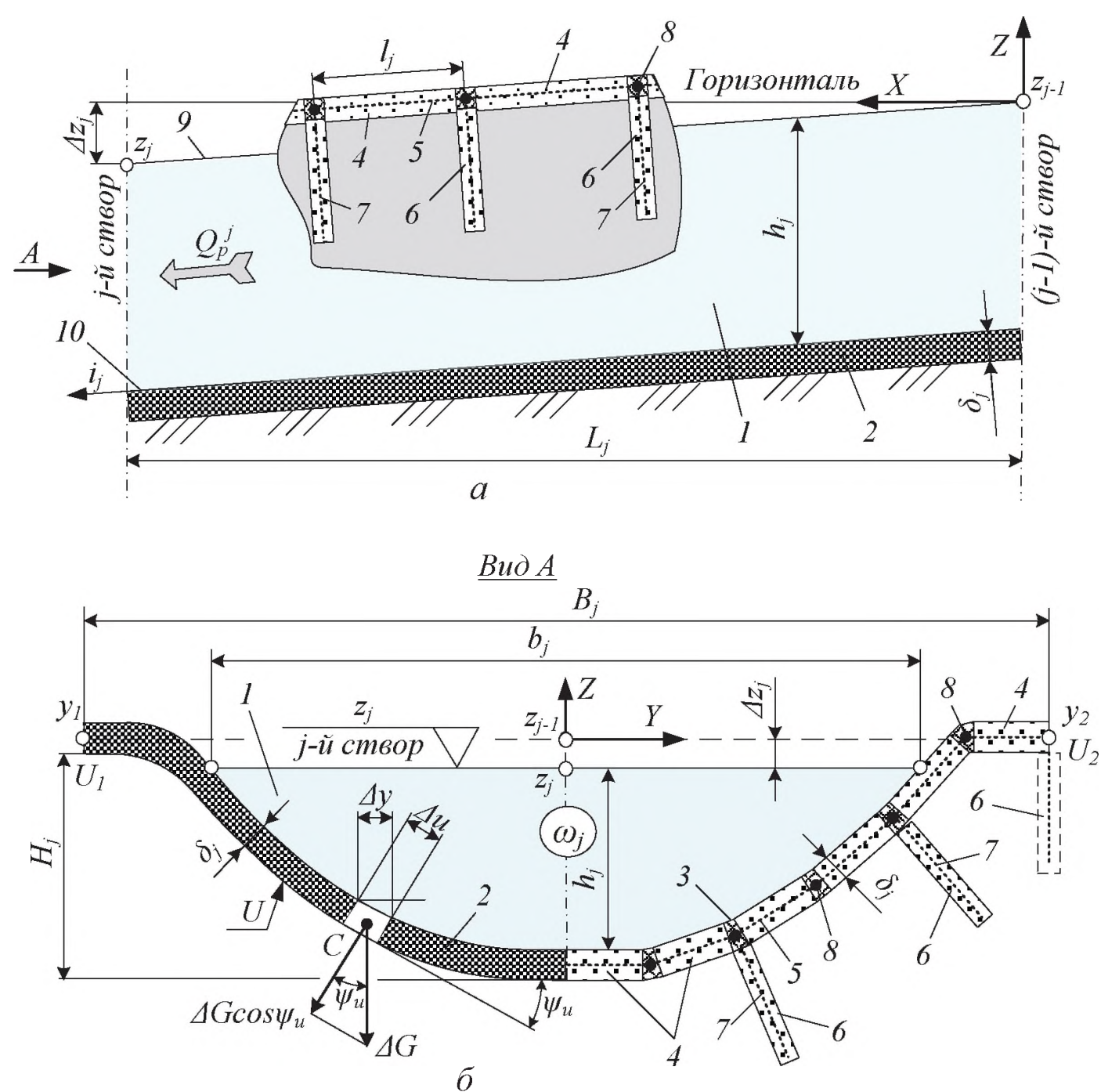

Рис. 1. Схема ј-ї ділянки русла річки:

a- подовжній переріз русла річки на ј-й ділянці; б- поперечний переріз русла річки на j-й ділянці (вид $A$ ); 1 - русло річки; 2 - берегоукріплювальне покриття з насипних кам'яних матеріалів; 3 - гнучке берегоукріплювальне покриття зв 'язаної конструкиіӥ з анкерним кріпленням; 4 -залізобетонний берегоукріплювальний блок; 5 -арматура блоку 4;

6 - залізобетонний анкер; 7 - арматура анкера; 8 - гнучке кріплення блоків до анкера; 9 - п'єзометрична лінія; 10 - поздовжня лінія дна річки. 
$F_{j}^{e-n}$ - сила тертя об’єму води $w_{j}$ об поверхню покриття, $H$.

Запишемо умови стійкості захисного покриття на земляній основі русла:

$$
P_{j}^{2 \grave{\partial}}=F_{j}{ }^{\beta-n}<F_{j}^{n-2 p}=k_{3 p}\left[F_{j}\right]^{n-2 p},
$$

де $F_{j}^{n-2 p}-$ сила тертя опірної поверхні покриття об грунтову основу русла, $\mathrm{H} ;\left[F_{j}\right]^{n-2 p}-$ гранична сила тертя опірної поверхні покриття в момент його зрушення на грунтовій основі русла, $\mathrm{H} ; k_{\text {зс }}-$ коефіцієнт запасу стійкості покриття, що комплексно враховує коливання гідродинамічних сил, нерівномірність розподілу сил тертя між поверхнею покриття i грунтом, похибки гідрологічних прогнозів тощо. Пропонується приймати $k_{3 p}=0,7$.

Граничну силу тертя $\left[F_{j}\right]^{n-2 p}$ доцільно визначати по частинах

$$
\left[F_{j}\right]^{n-2 p}=\left[F_{j}^{G}\right]^{n-2 p}-\left[F_{j}^{A}\right]^{n-2 p},
$$

де $\left[F_{j}^{G}\right]^{n-2 p}$ - гранична сила тертя опірної поверхні покриття об грунт без урахування впливу архімедової сили на занурену у воду частину покриття, $H ;\left[F_{j}^{A}\right]^{n-2 p}-$ зменшення сили тертя $\left[F_{j}^{G}\right]^{n-2 p}$ завдяки дії архімедової сили, $H$.

Силу $\left[F_{j}^{G}\right]^{n-2 p}$ представимо криволінійним інтегралом першого роду

$$
\left[F_{j}^{G}\right]^{n-\imath p}=\int_{U_{1}}^{U_{2}} \int_{x=0}^{L_{j}} \zeta d u d x=L_{j} \int_{U_{1}}^{U_{2}} \zeta d u,
$$

де $\zeta$ - питома сила тертя покриття об грунт, $\mathrm{H} / \mathrm{M}^{2} ; U_{1}, U_{2}-$ граничні параметри інтегрування сили Гвздовж лінії $U$ поверхні тертя, м.

Для визначення , виділимо у захисному покритті елементарний прямокутний паралелепіпед $C$ масою $A G$ зі сторонами $A u, A x, \delta$ (рис. 1). Знайдемо силу тертя елементарного паралелепіпеда $\Delta F_{u x}(\mathrm{H})$ у напрямі осі $X$ :

$$
\Delta F_{u x}=f \rho_{o n} g \delta_{j} A x A u \cos \psi_{u},
$$

де $f$ - коефіцієнт тертя підошви покриття

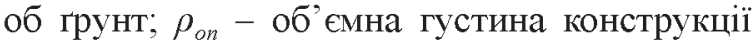

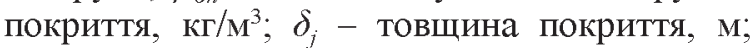
$\psi_{u}-$ кут нахилу укосу русла до горизонтальної площини (залежить від аргументу $u$ ), град.

Визначимо $\zeta$ для виділеного елементарного паралелепіпеда $C$ :

$$
\zeta=\Delta F_{u x} / \Delta x \Delta u=f \rho_{o n} g \delta_{j} \cos \psi_{u} .
$$

Введемо значення $\zeta 3$ (23) в криволінійний інтеграл (21)

$$
\left[F_{j}^{G}\right]^{n-\imath p}=L_{j} \int_{U_{1}}^{U_{2}} f \rho_{o n} g \delta_{j} \cos \psi_{u} d u
$$

Оскільки $\Delta u \cos \psi_{u}=\Delta y$ (рис. 1), то в підінтегральній функції інтегралу (24) доцільно зробити заміну аргументу $u$ на $y\left(\cos \psi_{u} d u=d y\right)$ при відповідних граничних параметрах інтегрування: $U_{1} \rightarrow y_{1}=-B_{j} / 2 ; U_{2} \rightarrow y_{2}=+B_{j} / 2$. Тоді силу $\left[F_{j}^{G}\right]^{n-2 p}$ визначають за допомогою звичайного інтегралу:

$$
\begin{aligned}
{\left[F_{j}^{G}\right]^{n-2 p} } & =L_{j} \int_{y=-B_{j} / 2}^{y=+B_{j} / 2} f \rho_{o n} g \delta_{j} d y= \\
& =f \rho_{o n} g \delta_{j} L_{j} B_{j},
\end{aligned}
$$

де $B_{j}$ - ширина русла (покриття по осі $Y$ ) 3 урахуванням берм, м.

Силу $\left[F_{j}^{A}\right]^{n-2 p}$ зменшення тертя від дії архімедової сили виштовхування визначають по аналогії 3 визначенням сили $\left[F_{j}^{G}\right]^{n-2 p}$ за допомогою інтегралу:

$$
\begin{aligned}
{\left[F_{j}^{A}\right]^{n-2 p} } & =L_{j} \int_{y=-b_{j} / 2}^{y=+b_{j} / 2} f \rho_{o n} \frac{\rho}{\rho_{M n}} g \delta_{j} d y= \\
& =f \rho_{o n} \frac{\rho}{\rho_{M n}} g \delta_{j} L_{j} b_{j},
\end{aligned}
$$

де $\rho_{\text {мn }}$ - густина матеріалу покриття, кг $/ \mathrm{M}^{3}$; $b_{j}$ - ширина дзеркала води, м.

Визначимо силу $\left[F_{j}\right]^{n-2 p}$, скориставшись залежностями (20), (25) i (26).

$$
\left[F_{j}\right]^{n-2 p}=f \rho_{o n} g \delta_{j} L_{j}\left(B_{j}-\frac{\rho}{\rho_{M n}} b_{j}\right) .
$$

Запишемо умову стійкості покриття (19) 3 урахуванням залежності (18) визначення гідродинамічної сили зрушення $P_{j}^{2 д}$ і залежності (27) визначення сили $\left[F_{j}\right]^{n-2 p}$ тертя при зрушенні покриття на поверхні грунтової основи русла:

$$
\rho g \omega_{j} i_{j} L_{j}=k_{\text {sp }} f \rho_{\text {on }} g \delta_{j} L_{j}\left(B_{j}-\frac{\rho}{\rho_{\text {sn }}} b_{j}\right),
$$

або після спрощення:

$$
\rho \omega_{j} i_{j}=k_{\text {зp }} f \rho_{o n} \delta_{j}\left(B_{j}-\frac{\rho}{\rho_{M n}} b_{j}\right)+
$$

Основним розрахунковим параметром покриття зв'язаної конструкції $є$ товщина $\delta_{j}$, тому умову стійкості покриття (28) доцільно записати так:

$$
\delta_{j}=\frac{\rho \omega_{j} i_{j}}{k_{3 D} f \rho_{O N}\left(B_{j}-\frac{\rho}{\rho_{M n}} b_{j}\right)} .
$$

Проектна товщина покриття $\delta_{j}$ зазвичай складає $0,3 \ldots 0,5$. Якщо розрахована за формулою (30) $\delta_{j}$ буде занадто великою, то для економії матеріалів приймається проектне рішення берегоукріплювального покриття зв'язаної конструкції з додатковими анкерами (рис. 1, поз. 6). 
7. Обірунтування захисного покриття русла річки зв'язаної конструкції з анкерними елементами

Обгрунтування параметрів гнучкого берегоукріплювального покриття зв'язаної конструкції 3 додатковими анкерами здійснюють на основі вищенаведених методичних засад 3 обгрунтування параметрів покриття зв'язаної конструкції, а також з урахуванням дії сил реакції грунту на анкери.

По аналогії 3 розрахунковими залежностями забезпечення стійкості покриття зв'язаної конструкції з урахуванням залежностей (18), (19), (28) і (29) запишемо умову стійкості покриття зв'язаної конструкції 3 анкерами:

$$
\begin{gathered}
P_{j}^{2 \partial}=k_{3 p}\left[F_{j}\right]^{n-2 p}+R_{j}^{a} \\
\rho \omega_{i} i_{i} L_{j}=k_{3 p}\left[f \rho_{o n} \delta_{j} L_{j}\left(B_{j}-\frac{\rho}{\rho_{M n}} b_{j}\right)+\right. \\
\left.+R_{0}^{a} \frac{L_{j}}{l_{j}} K_{j}^{a}\right]
\end{gathered}
$$

де $R_{j}^{a}$ - сумарна горизонтальна протизсувна сила реакції групи анкерів на $j$-й ділянці, $\mathrm{H} ; R_{o}{ }^{a}$ - горизонтальна сила реакції одного зануреного в грунт анкера, $\mathrm{H} ; K_{j}^{a}-$ кількість анкерів, встановлених в одному ряду поперечного перерізу ј-ї ділянки русла річки; $l_{j}-$ крок між рядами анкерів, м.

Розрахунковими параметрами покриття такої конструкції $є$ параметри його анкерного кріплення $R_{o}^{a}, l_{j}, K_{j}^{a}$, які обирають, користуючись формулою:

$$
R_{0}^{a} \frac{K_{l}^{a}}{l_{j}}=\frac{\rho \omega_{j} i_{j}}{k_{3 p}}-f \rho_{o n} \delta_{j}\left(B_{j}-\frac{\rho}{\rho_{s m}} b_{j}\right)
$$

Висновки. Через недосконалість існуючих науково-методичних розробок 3 обгрунтування конструктивних рішень та параметрів захисних протипаводкових покриттів русел гірських річок проекти захисних покриттів річок найчастіше розроблюють або $з$ недостатнім, абоо з занадто великим запасом їх стійкості до гідродинамічних навантажень, що в першому випадку призводить до руйнування паводковим потоком захисного покриття, а в другому випадку до невиправдано великих будівельних витрат.

Для вибору ефективних проектних рішень захисних протипаводкових покриттів русел гірських річок та розрахунку ї параметрів розроблено та запропоновано методику, в основу якої покладено два критерії: технічна надійність та економічна ефективність використання захисних покриттів.

Технічна надійність захисних покриттів оцінюється їх стійкістю до розмиву паводковим потоком та стійкістю до зрушення 3 грунтової основи русла річки силою гідродинамічного тиску. Стійкість захисних покриттів забезпечується використанням на стадії проектування запропонованої методики розрахунку їх конструктивних параметрів 3 урахуванням гідрологічних параметрів річки та морфометричних параметрів іiї русла.

Економічна ефективність захисних покриттів забезпечується запропонованою процедурою послідовного перебору та аналізу альтернативних варіантів захисних покриттів, починаючи 3 найбільш дешевого варіанту за показником будівельних та експлуатаційних витрат.

\section{Бібліографія}

1. Петроченко B.I. Методика визначення оптимальних розрахункових величин забезпеченості паводків на стадії проектування протипаводкових систем // Меліорація і водне господарство. 2017, №105. C. 99-106.

2. Справочник по гидравлике под редакиией Большакова В.А. - Киев : «Вища школа», 1977. $280 \mathrm{c}$.

3. Богомолов А.И., Михайлов К.А. Гидравлика. Москва : Стройиздат, 1972.648 c.

4. Константинов Ю.М., Гіжа О.О. Технічна механіка рідини і газу: Підручник. Київ : Вища икола, 2002. 277 c.

5. Берегоукріплювальне покриття / В.І. Петроченко, О.В. Петроченко : пат. 33748 Украйна: № u200802684; Заявлено 29.02.2008; опубл. 10.07.2008, Бюл. №̄ 13.

6. Покриття берегів водних об'сктів / В.І. Петроченко, А.М. Шевченко, Д.П. Савчук, О.В. Петроченко : пат. 86676 Україна: 스 и201307671; Заявлено 17.06.2013; опубл. 10.01.2014, Бюл. №1.

\section{References}

1. Petrochenko, V.I. (2017). Metodyka vyznachennya optymalnyx rozraxunkovyx velychyn zabezpechenosti pavodkiv na stadiyi proektuvannya protypavodkovyx system [Methodology for 
determining the optimal computed values of flood probability when designing flood control systems]. Kyiv: Melioraciya i vodne gospodarstvo, 105, 99-106. [in Ukrainian].

2. Bolshakov, V.A. (Ed.) (1977). Spravochnik po gidravlike [Handbook for Hydraulics]. Kyiv: Higher school. [in Russian].

3. Bogomolov A.I., \& Mikhailov, K. A. (1972). Gidravlika [Hydraulics]. Moscow: Stroyizdat. [in Russian].

4. Konstantinov, Yu.M., \& Gizha, O.O. (2002) Texnichna mexanika ridyny i gazu. Pidruchnyk. [Technical mechanics of liquid and gas]. Textbook. Kyiv: Higher school. [in Ukrainian].

5. Petrochenko, V.I., Petrochenko, O.V. (2008). Beregoukriplyuvalne pokryttya /Coast-protecting facing7. Patent of Ukraine. № 33748. [in Ukrainian].

6. Petrochenko, VI., Shevchenko, A.M., Savchuk, D.P., Petrochenko O.V. (2014) Pokryttya beregiv vodnyx obyektiv [Coating of bank water bodies]. Patent of Ukraine. № 86676. [in Ukrainian].

В.И. Петроченко, А.В. Петроченко

Обоснование защитных противопаводковых покрытий русел горных рек

Разработана методика обоснования конструктивных ремений и расчета параметров защитных противопаводковых покрытий русел горных рек. В основу методики положсен критерий устойчивости защитных покрытий к размыванию и сдвигу паводковым потоком расчетной обеспеченности. Методика предлагается для практического применения на стадии разработки проектов систем противопаводковой защиты.

Substantiation of coverage of the canal of a mountain river for protection against flood

V. I. Petrochenko, O. V. Petrochenko The technique of substantiation of constructive decisions and calculation of parameters of protective coatings on Mountain Rivers is developed. The basis of the technique is the criterion of the stability of protective coatings to erosion and displacement during the passage of flood calculated safety. The methodology is proposed for practical application at the design stage of flood control systems. 